\title{
ESTUDO SOBRE O REFLEXO DA CONSULTORIA CONTÁBIL DURANTE A PANDEMIA COVID - 19 EM EMPRESAS DE PEQUENO PORTE
}

\section{ARTIGO ORIGINAL}

MARQUES, Luana Ribeiro'1, BARBOSA, Elivelton Natan Steinheuser², GOMES, Karina Cristina Nogueira ${ }^{3}$, CARVALHO, Luhan da Silva ${ }^{4}$, ROBERTO, José Carlos Alves $^{5}$, SERRA, Meg da Rocha Cunha ${ }^{6}$, FERREIRA, Nelânia Lopes ${ }^{7}$

MARQUES, Luana Ribeiro. Et al. Estudo sobre o reflexo da consultoria contábil durante a pandemia covid - 19 em empresas de pequeno porte. Revista Científica Multidisciplinar Núcleo do Conhecimento. Ano. 06, Ed. 11, Vol. 13, pp. 135-161. Novembro de 2021. ISSN: 2448-0959, Link de acesso: https://www.nucleodoconhecimento.com.br/contabilidade/consultoria-contabil, DOI: 10.32749/nucleodoconhecimento.com.br/contabilidade/consultoria-contabil

\section{RESUMO}

Em decorrência do alastramento de casos de COVID-19 por todo o mundo, foram adotadas medidas de isolamento que alteraram o funcionamento de todos os setores da economia. A súbita queda do faturamento e paralisação das atividades demandaram forte controle gerencial de tomada de decisões. Tendo a Contabilidade como maior instrumento informativo da gestão, evidenciou-se a necessidade e versatilidade da consultoria contábil no auxílio das entidades mesmo em períodos adversos. Neste sentido, o trabalho almeja dar esclarecimentos ao seguinte questionamento: de que forma a consultoria contábil pode auxiliar na gestão empresarial de empresas de pequeno porte durante o período de crise? A presente

\footnotetext{
${ }^{1}$ Graduanda do curso de Ciências Contábeis.

${ }^{2}$ Graduando do curso de Ciências Contábeis.

${ }^{3}$ Graduanda do curso de Ciências contábeis.

${ }^{4}$ Graduando do curso de Ciências Contábeis.

${ }^{5}$ Orientador. Mestre em Engenharia de produção. Especialista Logística empresarial. Graduado em Administração com Ênfase em Marketing.

${ }^{6}$ Orientadora.

${ }^{7}$ Orientadora.
}

RC: 102106

Disponível em: https://www.nucleodoconhecimento.com.br/contabilidade/consultoria$\underline{\text { contabil }}$ 
pesquisa tem como objetivo apresentar os reflexos da pandemia no ramo empresarial das pequenas empresas e, consequentemente, nos setores internos das entidades, em especial no que concerne à posição financeira da empresa, às relações trabalhistas e às medidas governamentais para contenção da crise sanitária COVID-19. Para a realização do estudo, realiza-se uma pesquisa bibliográfica qualitativa descritiva, no intuito de buscar e analisar as possibilidades de solução que as ferramentas contábeis proporcionam ao segmento, mesmo em tempos de recessão. Desta forma, serão descritas estratégias de planejamento e procedimentos que os contadores podem executar para apoiar os empresários na gestão, na produção de prognósticos de capital de giro e no estudo de fluxo de caixa, além de relatórios e informações necessárias para assessorar na tomada de decisões gerenciais, de modo a garantir a saúde patrimonial da entidade como um todo.

Palavras-chaves: Consultoria Contábil, Pandemia, Pequenas Empresas, Ferramentas de Planejamento Estratégico.

\section{INTRODUÇÃO}

$\mathrm{Na}$ atualidade, a contabilidade deixou de ser encarada como uma ciência que se atém somente ao registro de livros de caixa para ser vista como um instrumento fundamental na tomada de decisões da gestão empresarial. Neste sentido, suas especificidades têm encontrado cada vez mais valorização no mercado, principalmente no que concerne ao aparato da contabilidade gerencial e suas ferramentas, numa possibilidade de mitigar os efeitos da crise econômica que assola o país.

O Instituto Brasileiro de Geografia e Estatística - IBGE (2020), constatou que houve o fechamento de aproximadamente 522,7 mil empresas somente no ano de 2020, em decorrência dos efeitos da pandemia. Estes problemas econômicos foram agravados devido à necessidade de paralisação de atividades e das restrições de circulação legislativamente impostas. Com isso, a diminuição de vendas e 
prestações de serviços ocorreram de modo súbito, afetando diretamente os rendimentos e o departamento financeiro das empresas de pequeno porte. Diante de tal situação, a contabilidade gerencial passou a servir como instrumento determinante para reduzir tais consequências financeiras em território nacional.

Neste sentido, estudos que possam demonstrar de que modo funcionam as ferramentas contábeis, aliadas ao planejamento estratégico, que serve de base para melhorar os negócios e as relações trabalhistas em meio à pandemia, podem ser de grande valia para a retomada empresarial. Outrossim, ainda perduram muitos mitos, e até mesmo desconhecimento, a respeito do assunto no segmento de empresas de pequeno porte.

Perante tal situação, a problemática motivadora da pesquisa foi: de que forma a consultoria contábil pode auxiliar na gestão empresarial das empresas de pequeno porte durante o período de crise? A presente pesquisa tem como objetivo exemplificar as ferramentas da contabilidade gerencial e sua relação com os aspectos trabalhistas, especialmente em pequenas empresas, e demonstrar a correlação entre a crise e o departamento pessoal nos negócios, além do apoio fundamental que o setor contábil presta para a manutenção de atividades financeiras dentro de um estabelecimento.

Ademais, também serão retratadas algumas medidas econômicas e governamentais referentes ao período da crise, as quais ressaltam a importância do profissional contábil para a produção de relatórios, controle de fluxo de caixa, prognósticos de capital de giro e os ajustes legislativos necessários a um bom planejamento estratégico financeiro.

Esperamos que, ao final do artigo, a devida relevância tenha sido dada no que concerne ao valor das informações contábeis para os pequenos negócios, de modo a apoiar os gestores nas tomadas de decisão que poderão decidir o futuro de sua empresa. Deste modo, o número de fechamentos dos negócios poderá ser mitigado 
durante a vigência da pandemia, com prioridade em emprego e auxílio na retomada dos pequenos empreendimentos.

\section{FUNDAMENTAÇÃO TEÓRICA}

O referencial teórico consiste em uma análise de revisão literária a partir de um conteúdo de pesquisa, que deve conter pensamentos de diferentes autores. O desenvolvimento do referencial teórico é importante para a construção de um artigo, visto que está presente em diversas fases do projeto, sendo elaborado com as mais recentes pesquisas e obras científicas, através de citações diretas e indiretas, em consonância com a NBR 10520/2002 (OLIVEIRA, 2011).

\subsection{EMPRESAS DE PEQUENO PORTE}

Em virtude do valor das pequenas empresas para o aspecto econômico no Brasil, foi criado, em 2006, por intermédio da Lei Complementar no 123 de 14 de dezembro de 2006, o "Estatuto Nacional da Microempresa e da Empresa de Pequeno Porte", conhecido como a Lei Geral da Micro e Pequena Empresa. Este instituto legal foi estabelecido no intuito de trazer regulamentação ao que está disposto no artigo 179 da Constituição Federal, o qual assegura uma visão diferenciada para as microempresas e EPP's no país, de modo a incentivar sua expansão e permanência no mercado. Isso trouxe a possibilidade de tratamento diferenciado para este tipo de negócio em muitos segmentos econômicos, tais como o ramo previdenciário, tributário, jurídico, financeiro, além de outras situações legais (Costa; Leandro, 2016).

Os pequenos negócios são fundamentais no crescimento socioeconômico do país, pois oferecem empregabilidade e rendimento à população brasileira. De acordo com o Sebrae (2020), representam cerca de $27 \%$ do produto interno bruto (PIB) e empregam $52 \%$ da mão de obra formal. Ademais, representam cerca de $40 \%$ do teto salarial brasileiro, com crescimento satisfatório e com aumento anual gradativo. Tais 
estatísticas comprovam a relevância de impulsionar e qualificar o crescimento dessas empresas.

No Brasil, foi regulamentada a lei $123 / 2006$, que trata a respeito do regime tributário Simples Nacional, responsável por abarcar cerca de 14.812.240 (quatorze milhões, oitocentos e doze mil) empresas de pequeno porte. $O$ estatuto possui o intuito de alavancar o crescimento e o desenvolvimento dessas empresas, além de representar um meio para manter a geração de empregos no país, por intermédio dos pequenos negócios.

O estatuto também foi pensado como um meio de melhorar o sistema econômico brasileiro, com o objetivo de reduzir as dificuldades no processo de aberturas de empresas de pequeno porte e de diminuir o número de serviços informais (PEREIRA, 2010). No entanto, os últimos acontecimentos mundiais no tocante à saúde trouxeram inúmeros agravantes para a continuidade saudável dos pequenos negócios no país, o que fez com que a eficácia e abrangência da Lei 123/2006, no que concerne ao apoio ao empreendedor, também diminuísse.

Embora as empresas de pequeno porte tenham um papel fundamental no andamento da economia brasileira, e, inclusive, auxiliem na criação de novos postos de trabalho, conforme seu exponencial crescimento tem demonstrado, as dificuldades financeiras já existentes foram agravadas pela COVID-19, o que desacelerou ainda mais seu progresso, e ocasionou inúmeros fechamentos e paralisações no mercado.

Tal situação ressaltou ainda mais o papel desempenhado pelas micro e pequenas empresas no desenvolvimento e crescimento econômico local, em vista do aumento do desemprego em diversas regiões do país, o que levou à criação de novas políticas públicas voltadas para seu auxílio e benefício, de modo que suas atividades pudessem ainda existir (Pessôa; Costa; Maccari, 2016). Isso também se deve à perda de força da Lei 123/2006 quanto à sua capacidade de impulsionar isoladamente os pequenos negócios, o que fez com que os estabelecimentos 
necessitassem ainda mais de ferramentas para lhes auxiliar a escapar da crise iminente.

\subsection{PANDEMIA E O COVID-19}

Segundo a Organização Pan-Americana de Saúde - OPAS [2020?], o primeiro alerta oficial da Covid-19 relatado à Organização Mundial de Saúde (OMS) ocorreu na cidade de Wuhan, na China, em dezembro de 2019. No ano seguinte, os infectologistas chineses confirmaram que se tratava de um novo tipo de coronavírus, - SARS-CoV 2, que causa uma síndrome viral respiratória aguda. A doença passou a ser conhecida como COVID - 19.

Logo depois do primeiro caso da doença, a China chegou a registrar cerca de 11.821 casos, além de 259 mortes, o que ocasionou, em janeiro de 2019, o alastramento da doença por outros continentes. Foram então registrados casos na Europa, Ásia e América do Norte (Cavalcante et al., 2020).

Com o aumento nos números de casos e mortes ocasionada pela COVID -19, a Organização Mundial de Saúde declarou o surto desta nova variante do coronavírus no dia 30 de janeiro, e foi classificada como pandemia em 11 de março de 2020 (OPAS, 2020). No Brasil, o primeiro caso identificado foi em fevereiro de 2020, no Estado de São Paulo (Portal G1, 2020), e logo em seguida o vírus se espalhou por todo país.

Para evitar o aumento do contágio, o governo estabeleceu leis e decretos restringindo a circulação de pessoas, fator que afetou diretamente a circulação de bens de consumo, além do setor comercial e varejista. O distanciamento social, necessário para preservar a saúde, acelerou a crise econômica e trabalhista no país. A partir de então, a população brasileira, principalmente aqueles de mais baixa renda, viram-se com poucos recursos e incapazes de manter uma rotina de trabalho. Com a paralisação dos comércios e serviços, muitas empresas de pequeno porte fecharam seus negócios devido à falta de faturamento e impossibilidade de vendas. 
Ana Cristina Campos (Agência Brasil, 2020) afirma que os efeitos da pandemia afetaram negativamente as atividades de cerca de 2,8 milhões de empresas, o maior impacto foi nas empresas com até 49 funcionários, conhecidas como empresas de pequeno porte, onde o efeito negativo chegou a $62,7 \%$. Ainda segundo o site, cerca de $52,9 \%$ das empresas de pequeno porte em atividade tiveram problemas para realizar pagamentos, $43,9 \%$ relataram ter adiado o pagamento de impostos e cerca de $12,4 \%$ conseguiram algum tipo de linha de crédito emergencial para realizarem o pagamento dos funcionários.

\subsubsection{CENÁRIO ECONÔMICO}

Desde o início da pandemia, o mundo passou por várias mudanças, no intuito de conter o colapso viral, desde o distanciamento social até a interrupção das atividades econômicas, que, por conseguinte, ocasionaram um cenário de crise global. O mundo começou a lidar com uma situação de desconformidade, pois a retração da economia afetou o comércio internacionalmente e provocou o fechamento de fronteiras de vários países.

Determinados economistas passaram a apelidar a crise econômica de corona-crise, igualando-a à grande depressão dos anos de 1929. No entanto, a crise econômica não foi provocada pela crise sanitária, ela apenas acelerou o processo, pois a economia já se apresentava instável anteriormente no país (CARDOSO, 2020).

No Brasil, os efeitos econômicos já eram sentidos, devido às intervenções comerciais e isolamentos que já vinham ocorrendo na Ásia e Europa, o que gerou a redução no comércio exterior, ou seja, a crise sanitária desestabilizou a economia antes mesmo do vírus chegar ao Brasil $(G 1,2020)$.

O momento mais crítico da crise econômica no Brasil ocorreu entre abril e maio de 2020, em vista da paralisação do comércio (mais especificamente atividades consideradas não essenciais), o que provocou um decréscimo na economia e diminuiu as linhas de produção. Fatalmente, isso trouxe a demissão de 
trabalhadores e um faturamento exponencialmente menor, principalmente às pequenas empresas, além do equívoco da oferta de crédito pelo setor bancário, devido ao aumento do risco de investimento.

Para promover a contenção da crise econômica, o governo brasileiro passou a designar medidas que foram instituídas nas áreas sociais da saúde, empregos, firmas e em subnacionais, de modo a promover novas políticas de incentivos fiscais diretamente ligadas à área da contabilidade, no intuito de assegurar o bem-estar da população e a continuidade das empresas. Tais medidas destinaram-se também à salvaguarda das pequenas instituições, no entanto, possuíam caráter temporário, de modo que se mantiveram em vigor no período da crise econômica e foram encerradas, em grande parte, ainda em 2020 (ORELLANA, 2021).

Considerando o panorama de queda econômica e a necessidade de novas portas de saída para mitigação da crise, pode-se dizer que a contabilidade se consolidou como um dos grandes diferenciais para as empresas de pequeno porte dentro do período pandêmico, dado o valor das ferramentas de gestão contábil e suas relações com a legislação nacional para a continuidade dos pequenos negócios. Neste sentido, Krueger (2020) estabelece que a ciência contábil se demonstra como uma espécie de "barômetro" para as alterações internas e políticas na empresa, de modo que se relaciona tanto com os tipos de estratégias adotadas quanto com o contexto social que permeiam os negócios, o que torna o uso de suas ferramentas vital para a continuidade saudável das instituições.

\subsection{A CONSULTORIA CONTÁBIL}

A consultoria contábil tem como função apoiar as organizações nas principais tomadas de decisões, sendo essencial para as grandes organizações, além de melhorar e aprimorar os resultados patrimoniais da empresa. Ela é capaz de prever as técnicas a respeito das necessidades e inseguranças de um mercado que se modifica constantemente (OLIVEIRA, 2013). 
Com o cenário de estagnação econômica, a consultoria contábil tornou-se ainda mais fundamental nas organizações, orientando, analisando e buscando formas de diminuir os efeitos causados pela pandemia. Com as medidas provisórias estabelecidas pelo governo, os escritórios de contabilidade passaram a acelerar seus trabalhos, tendo que se adaptar às novas rotinas para garantir a permanência das empresas frente ao mercado.

Conforme Alvarenga (2020), dados revelam que os profissionais da contabilidade passaram a ter um aumento nos serviços, visto que, com as alterações na legislação, ocorreu um impacto direto nas questões tributárias e nas relações entre empresa e empregado. Em outras palavras, pode-se dizer que os profissionais da área passaram a reforçar suas tarefas para amparar os clientes em seus negócios, por intermédio das ferramentas de gestão contábil.

As determinações da consultoria contábil consistem em ensejar, contribuir e apoiar, todos os dias, milhares de entidades empresariais, desde o microempreendedor até as grandes corporações, alavancando negócios e carreiras. Seu trabalho embasado no conhecimento científico promove ainda mais avanço aos estabelecimentos que utilizam seus serviços.

\subsubsection{OBJETIVOS DA CONSULTORIA CONTÁBIL}

Para Schultz (2016), a execução das ocupações envolve uma ampla gama de atividades essenciais que direcionam os usuários ou empresas a realizarem suas funções e a atingirem suas metas e resultados. Seus principais objetivos são:

- Identificar as exiguidades do negócio;

- Executar técnicas;

- Propor mudanças;

- Alcançar benfeitorias e melhorias.

O profissional contábil é convocado a detectar o que levou a corporação a estar no quadro corrente, inspecionando e subscrevendo as causas, problemas e fatos da

RC: 102106

Disponível em: https://www.nucleodoconhecimento.com.br/contabilidade/consultoria$\underline{\text { contabil }}$ 
instituição. Para isso, se utiliza de inúmeras ferramentas especializadas. A aplicação de avaliações de desempenho, por exemplo, é um dispositivo irrefutável quanto aos seus diagnósticos. $\mathrm{O}$ aplicador estuda e compreende as amostragens e, a partir disso, põe em prática os procedimentos contábeis, marcados na história por suas prerrogativas de excelência na execução e beneficiamento.

Observa-se que os desígnios da orientação contábil compreendem, também, nortear os empreendedores sobre os assuntos financeiros com apoio dos relatórios contábeis fundamentais, tais como a demonstração do resultado do exercício (DRE), os livros contábeis, o balancete e o balanço patrimonial. São relatórios essenciais para a tomada de decisões estratégicas nas organizações (ALMEIDA et al., 2018).

Quanto às empresas de pequeno porte especificamente, estas devem fazer uso, primordialmente, da gestão contábil para a evolução do negócio, pois, conforme Barella (2014), o emprego de tal ferramenta pode ser útil não somente à administração da pequena empresa, mas também ao acesso ao fluxo de dados básicos contábeis, de modo a colaborar com o processo de tomada de decisão do gestor.

\subsection{GESTÃO EMPRESARIAL}

Uma parte elementar da existência de uma pequena empresa é sua equipe de gerenciamento. Os responsáveis pelo negócio geralmente contam com uma equipe formada por profissionais capacitados em determinados segmentos, capazes de auxiliar no fluxo de informações de forma bilateral, trazendo à sua diretoria o feedback do dia a dia, ao mesmo tempo que orientam os trabalhadores $e$ desenvolvem o projeto comercial do estabelecimento.

Dada a importância de tais profissionais, é fundamental que haja um bom gerenciamento contábil para o desenvolvimento da organização (STAGE, 2019). Logo, ao relacionarmos a necessidade do gestor de obter dados que explicitem os impactos do período pandêmico na entidade empresarial em que atua, juntamente 
com a qualidade informativa das demonstrações contábeis, pode-se dizer que a gestão da empresa necessita dispor de um sólido acompanhamento contábil, trazendo em seu arcabouço dados que englobam os seguintes gastos:

- Custos;

- Despesas;

- Investimentos;

- Perdas.

Portanto, para os usuários do sistema contábil que desejam (em um período emergencial como o da pandemia do Coronavírus) mitigar gastos, o gerenciamento de informações possui grande utilidade nesse aspecto, pois apresenta a capacidade de registro e contabilização de todo e qualquer valor que tenha sido movimentado na empresa. Conforme afirma Padoveze (2012), a gestão empresarial diz respeito ao fornecimento de dados por uma equipe à chefia - ou seja, estão dentro da empresa e são incumbidos pela diretoria a dar vazão às atividades operacionais.

O gerenciamento é imprescindível nas organizações, assim como o contabilista, pois orienta o direcionamento das informações escrituradas. Para a corporação apresentar sucesso e instabilidade é indeclinável que a gestão empresarial e a contabilidade estejam aliadas, uma vez que a não interpretação das informações pelos usuários atrasa o sucesso (CHIAVENATO, 2018).

O uso da informação contábil como instrumento de colaboração para a tomada de decisões acontece perante a necessidade do gestor (CREPALDI, 2012), semelhante ao que se tem visto atualmente com a pandemia, que tem afetado fortemente as relações consumeristas no país. Portanto, os dados do estabelecimento devem ser analisados de acordo com certos mecanismos, e devem ir ao encontro das ferramentas contábeis gerenciais, principalmente em meio à crise.

Não é de hoje que as pequenas empresas passam por enfrentamentos diários em prol de sua sobrevivência no mercado brasileiro, o que reforça ainda mais a necessidade de utilização das informações que podem servir como alavanca para

RC: 102106

Disponível em: https://www.nucleodoconhecimento.com.br/contabilidade/consultoria$\underline{\text { contabil }}$ 
seu trabalho. $O$ acesso às ferramentas contábeis por parte do empresário é fundamental para que ele possa exercer suas atividades e realizar as melhores decisões (LACERDA, 2016).

Ademais, o gerenciamento contábil abarca muitas ferramentas manuais ou digitais, que se traduzem no uso propriamente dito da contabilidade, tais como: o planejamento tributário, o planejamento financeiro, a utilização da legislação nacional, o fluxo de caixa e, principalmente, o instituto do planejamento estratégico no tocante às medidas governamentais e às medidas de enfrentamento econômico atual do país, que visa à melhoria do fluxo de caixa.

Padoveze (2012) diz que a contabilidade gerencial congrega todos os demais instrumentos de contabilidade que complementam a contabilidade financeira, para tornar a informação contábil efetiva em todos os processos de gestão dentro das empresas.

\subsubsection{IMPACTOS FINANCEIROS}

A crise sanitária mundial do Coronavírus, que se iniciou em meados de 2019, provocou grande impacto, especialmente no que diz respeito às pequenas empresas. As medidas de restrição geraram inegáveis baixas econômicas em segmentos empresariais em todo o mundo. A paralisação das atividades consideradas não essenciais e o confinamento causaram, em 2020, uma retração do produto interno bruto (PIB) no Brasil, no valor de 4,1\% (IBGE, 2020).

Inúmeras companhias fecharam as portas, algumas mudaram seus nichos de atuação e outras se reinventaram. A decadência manifestou situações adversas para o século, e dentre elas houve ocasiões em que os empresários viram seus negócios diluírem-se. Em meio a todo o cenário de caos, muitas pequenas empresas pararam de existir ou continuaram trabalhando somente por intermédio de uma pessoa: seu fundador.

RC: 102106

Disponível em: https://www.nucleodoconhecimento.com.br/contabilidade/consultoriacontabil 
Tal contexto gerou uma debilidade econômica mundial, além de ocasionar a desvalorização de moedas, a queda de ações de grandes empresas em bolsas de valores, além do próprio aumento inflacionário em países de terceiro mundo que dependiam de importações ou exportações de determinados produtos (MATTEl; FRONZA; HEINEN, 2020).

De acordo com o portal de notícias G1 (2020), a recessão sanitária causou altas perdas na Bolsa de Nova York, visto que, nos Estados Unidos, registrou-se um péssimo índice de PIB no 1ํtimestre, algo que não acontecia desde o ano de 1987. Considera-se que o mercado perdeu aproximadamente cerca de US \$14 trilhões. Perderam-se os rendimentos de inúmeras firmas, e as mais afetadas foram as do segmento de turismo, automóveis e tecnologias.

Os indicadores financeiros vitais demonstravam que a economia no Brasil já apresentava um mau desempenho desde 2015. Nesse período, o PIB brasileiro já apontava taxas negativas (MATTEI; FRONZA; HEINEN, 2020). As entidades empresariais, que possuíam seu maior déficit no fluxo de caixa, recorreram à modalidade de teletrabalho para desempenhar suas atribuições, pois tinham em vista que encerrar suas atividades não era a melhor opção. Esses dados demonstram que houve certa adaptação neste período de tribulação que se estendeu aos funcionários, e que, por fim, muitas empresas aderiram a modalidade home office.

\subsubsection{ESTRATÉGIAS PARA MANTER OS NEGÓCIOS ATIVOS}

Um fator crucial para a melhoria das empresas em meio à crise é a fixação de um planejamento tributário específico, embasado na legislação. Ao incorporar estratégias e ações definidas para que o estabelecimento siga um curso com perspectivas para possíveis cenários econômicos, a contabilidade propõe ideias que promovem uma possível estabilidade futura, ainda que em tempos de crise. Neste sentido, Segato (2020) aponta que há diversas ferramentas elementares que poderão ser usadas para a criação de uma estratégia contábil dentro do 
estabelecimento, tais como: os custos variáveis, a formação de preço dos produtos, o balanço de patrimônio, o fluxo de caixa e até mesmo o demonstrativo do resultado de exercício financeiro para a produção de resultados da empresa.

Primeiramente, podem ser apontadas as informações de entrada e saída de capital no estabelecimento a partir da negociação de seus produtos. Tais dados auxiliam na montagem de um bom planejamento financeiro, à medida que ampliam a visão do fluxo de caixa por intermédio dos demonstrativos de resultado do exercício.

Esta ferramenta pode realçar os lucros/ perdas em determinado intervalo de tempo na empresa, o que possibilita o trabalho de problemáticas envolvendo produtos com variáveis de preço desajustado ou aumento excessivo de devoluções (LEMES; PISA, 2010).

Já no que se refere às questões fiscais, como ferramentas de planejamento empresarial, Oliveira (2013) afirma que se pode compreender tal medida como uma maneira lícita para a redução de encargos e mitigação de taxas governamentais, o permite o favorecimento a empresa dentro das legislações existentes. É esperado, no entanto, que o profissional contábil esteja apto a realizar o melhor enquadramento possível no regime tributário, e que ele se adeque às perspectivas factuais da Instituição, de modo que some possíveis isenções ou linhas de crédito público a outras ferramentas da contabilidade para a realização de um planejamento adequado.

Vê-se, neste ponto, o valor das informações contábeis para propositura de soluções gerenciais dentro do planejamento financeiro do pequeno negócio, em vista que as empresas possuidoras de boa consultoria contábil são capazes de reduzir custos e se precaver de possíveis desequilíbrios no mercado. Os aspectos disponíveis pelos registros contábeis direcionam-se à raiz dos problemas (SOUZA; PINHEIRO, 2015). 


\subsection{A CONTABILIDADE}

A Contabilidade é uma ciência social que permite o fornecimento das mais variadas informações a respeito das entidades e tem como finalidade basear a correta tomada de decisões dos gestores das empresas (SEGATO, 2020).

A Contabilidade é descrita na Deliberação CVM no 29/86, como um sistema provedor de demonstrações de caráter econômico, financeiro e físico e de produtividade, que tem como base a empresa. Por isso, endossa-se que ela venha a atuar de modo provedor aos gestores, de modo a garantir dados comparativos variados entre diferentes períodos de atuação das atividades operacionais da Instituição, para demonstrar: seus custos, suas despesas, seu faturamento, entre outros, mesmo em tempos de crise, possibilitando a utilização de suas ferramentas para suporte no planejamento estratégico.

Classificada como atividade essencial, a Contabilidade se manteve operante diante do momento de crise, em que ocorreu uma massificação de informações legislativas e o profissional contábil demonstrou ser útil a gestão da empresa ao conseguir conciliar as obrigações acessórias às novas medidas provisórias, instruções normativas e mudanças de prazos, além das próprias ferramentas da gestão contábil (CONRADO, 2020).

As Ciências Contábeis apresentam técnicas que garantem resultados assertivos sobre diversas variáveis do comportamento interno e permite apresentá-los de forma quantitativa e qualitativa ao gestor, o que reitera a ideia de que esta ciência funciona como um guia auxiliar na gestão dos negócios (SOUZA; PINHEIRO, 2015).

A versatilidade na atuação da Contabilidade permite controlar, mensurar e avaliar os fatos administrativos de entidades empresariais, de modo a se estender a todos os objetos sociais, independente do segmento do negócio (indústria, prestação de serviços e comércio). O pilar fundamental da contabilidade é fornecer aos interessados (sejam estes do segmento econômico ou não) dados concretos o 
bastante para que possam suportar diversos contextos de instabilidade e propiciar decisões assertivas e dinâmicas (MOREIRA et al., 2013).

Quanto à figura do profissional para o estabelecimento de metas, sua contribuição vem da utilização de todas essas ferramentas apontadas e desenvolve metas reais a partir dos relatórios de caixa, dos fluxos de mercadoria e da demonstração de resultados dentro de um exercício financeiro. Já ao pequeno empresário, cabe apresentar a realidade do seu negócio, de modo que a contabilidade análise todos os dados disponíveis e se posicione no presente e para o futuro, de forma que aponte causas e efeitos para solução de crises econômicas.

Conforme Lima; Castor e Costa (2018), o mundo está em constante mudança, uma vez que o profissional contábil é capaz de estabelecer projeções do negócio que englobam o todo (passado, presente e futuro), e isso representa uma colaboração de grande importância para tomada de decisões.

\subsubsection{AS FERRAMENTAS CONTÁBEIS NAS RELAÇÕES TRABALHISTAS NO PERÍODO DA PANDEMIA}

As Ciências Contábeis se apresentam como uma grande ferramenta informativa. Dentre sua grande gama de ramificações, podemos notar algumas ações próprias do profissional contador que cabem ao segmento trabalhista e que auxiliam para que os direitos trabalhistas dos colaboradores sejam respeitados, bem como seus deveres sejam cumpridos. No entanto, é válido ressaltar que o período delicado de recessão, que se estende desde 2019 até o presente momento, fragilizou fortemente as relações trabalhistas e de emprego no país (GANDRA, 2020).

De acordo com o Instituto Brasileiro de Geografia e Estatística (IBGE, 2021), no primeiro trimestre de 2021 foram registrados 14,1 milhões de desempregados, número similar ao recorde do mesmo período do ano passado. Este resultado pode ser associado aos impactos causados pela pandemia que, de certa forma, tornou as relações de emprego mais instáveis, principalmente dentro das empresas de

Disponível em: https://www.nucleodoconhecimento.com.br/contabilidade/consultoria$\underline{\text { contabil }}$ 
pequeno porte. Os índices apontam uma considerável redução de fluxo nos segmentos de consumo, indústria e de serviços.

Tais padrões são decorrentes da necessidade de isolamento social, haja vista que estão intimamente conectados à presença constante de clientes. A quebra da demanda trouxe instabilidade ao mercado e impossibilitou que houvesse uma permanência na oferta de tais setores (GANDRA, 2020).

As medidas de distanciamento social paralisaram substancialmente as atividades empresariais que não podiam ser executadas de forma remota, o que fez com que o faturamento de tais entidades registrasse baixas consideráveis e trouxesse uma dificuldade maior no fechamento das obrigações trabalhistas. Isso também resultou no aumento expressivo de solicitações referentes ao seguro-desemprego, com uma crescente aproximada de 39\% (IRAJÁ, 2020).

A versatilidade do profissional contábil the dá propriedade para atuar em diversos procedimentos relacionados ao departamento pessoal da empresa. Processos como folhas de pagamento, benefícios, aplicação de instruções vindas de convenções coletivas de trabalho (CCT) e apuração de impostos estão inclusos nas funções profissionais do contador.

Sendo assim, é possível estabelecer que o contabilista, por meio das técnicas contábeis, poderá sugerir e/ou definir métodos de operação internos que conciliam as obrigações trabalhistas da empresa ao status econômico, a fim de mitigar riscos referentes ao desemprego desencadeado por períodos de recessão (DIAS FILHO; SALLES, 2014). A clareza nos relatórios contábeis é primordial para evidenciar os valores concernentes à folha e encargos de todos os departamentos da empresa, já que embasa decisões dos gestores em sentido macro.

Este tipo de operação oferece mais estabilidade à relação trabalhista, além de dar solidez à realocação de valores dentro do pequeno negócio, o que faz com que possam ser distribuídos aos departamentos mais carentes de melhorias ou adaptações perante a crise.

RC: 102106

Disponível em: https://www.nucleodoconhecimento.com.br/contabilidade/consultoria$\underline{\text { contabil }}$ 
Neste sentido, é importante dar ênfase também ao instituto da MP trabalhista 1046/2021, que permitiu a redução de gastos com um departamento custoso para priorizar férias de funcionários que pudessem ser remanejadas (procedimento utilizado como forma de manter o funcionário ativo na empresa, afastando-o, mas de forma remunerada, de modo a manter o distanciamento social), ainda que antes de seu período aquisitivo. Tal atividade está intimamente ligada à contabilidade e a gestão do negócio, e consolida a estrita relação entre o profissional contábil e a legislação trabalhista (CONRADO, 2020).

De acordo com Oliveira e Ferreira (2019), o profissional contábil tem a capacidade de atuar para evitar autuações trabalhistas aos empregadores, geradas pela falta de conhecimento a respeito da legislação. Nesse quesito, é válido ressaltar que é esta mesma atuação que diretamente concilia a relação trabalhista e promove um bemestar social, pois auxilia na não estagnação das atividades da empresa que necessitam de mão-de-obra e mitiga os desligamentos.

\subsubsection{MEDIDAS GOVERNAMENTAIS DURANTE O PERÍODO DA PANDEMIA}

O Governo detém muitas funções e responsabilidades no funcionamento de uma sociedade. Configura-se, principalmente, como sua função, promover meios para o crescimento econômico da nação e assegurar direitos constitucionais a sua população. Neste sentido, pode ser compreendido como uma composição do Estado, em que um conjunto de indivíduos têm por função promover através de decisões, meios para guiar a sociedade (RODRIGUES, 2010).

Ao se considerar que a Contabilidade consiste em uma ciência que engloba aspectos econômicos, fiscais e trabalhistas, torna-se responsabilidade do profissional contábil conciliar as obrigações com a legislação vigente para eximir a empresa de autuações e multas e conciliar o planejamento tributário com o máximo de redução fiscal dentro da licitude no negócio e o mínimo de necessidade de desemprego aos funcionários.

RC: 102106

Disponível em: https://www.nucleodoconhecimento.com.br/contabilidade/consultoriacontabil 
De acordo com Encarnação et al. (2013), a fragilidade das micro e pequenas empresas está diretamente ligada à escassez de informações de teor contábil, o que torna o processo de tomada de decisão mais arriscado. Logo, se faz possível concluir uma relação entre a maior dificuldade do pequeno empresário em acompanhar, analisar e pôr em prática vigente as medidas governamentais que vem de auxílio ao seu negócio. Diante de tal inaptidão, cabe à figura do profissional contábil e ao gerenciamento de informações apoiá-lo perante as legislações na crise.

Dentre as principais medidas governamentais que se estabeleceram em razão do período pandêmico, tem-se a implementação de Medidas Provisórias (MP trabalhista 1046/2021), que foram amplamente efetivadas para contornar os impactos da crise sanitária. Essas medidas consideradas emergenciais flexibilizaram procedimentos que se estendem do departamento fiscal ao pessoal e que consequentemente refletem na dinâmica do financeiro. Também houve a postergação do pagamento de tributos como o FGTS, parcelamento de dívida tributária, antecipação de férias coletivas, entre outros. Esses foram os mecanismos que a União disponibilizou para tentar evitar o fechamento de negócios de variados segmentos (Lei 14.020/2020).

Outro exemplo do uso de medidas governamentais que também se encaixam na contenção da crise é o advento da MP 944/2020, responsável pelo programa de empréstimos para pagamento de folha às empresas com receita bruta de $R \$$ 360.000 e R $\$ 50.000 .000,00$, no período de 2019. Cabe à contabilidade gerencial estar atenta às estratégias e possibilidades governamentais que possam mitigar os prejuízos financeiros e até mesmo salvar os pequenos negócios, ainda que em tempos difíceis.

Para relacionar a atuação da Contabilidade como utilitária na interpretação e aplicação dessas medidas às rotinas da empresa configuradas como pequenos negócios, pode-se reiterar a sua capacidade em analisar o comportamento financeiro do negócio, levando em consideração seus gastos com tributação e custos de departamentos anterior a implementação das medidas governamentais, e 
traçar uma estratégia interna que permita conciliar estas obrigações às decisões da gestão para manter o negócio operante, enquanto, ainda com auxílio do próprio utilitário sistema contábil, se faz possível embasar ações futuras que contribuam com o contorno da crise (SOBRAL; CARDOSO; SANCHES, 2017).

Portanto, a orientação do contador deve ser analisada como a oportunidade de os empresários manterem e melhorarem seus negócios, uma vez que traz consigo todas as ferramentas capazes de cumprir com o estabelecido, inclusive no que diz respeito às soluções legislativas durante a pandemia.

Trata-se de medidas que englobam iniciativas envoltas na eficácia dos investimentos para desenvolvimento do trabalho em vários níveis, que se relacionam aos sistemas de informação e às variáveis que possam afetar o fluxo de caixa e o balanço patrimonial, tais como: delivery, home office, drive thru, vendas online, telemarketing e mídias sociais, além de operações desempenhadas com base em estratégias possíveis, diretamente conectadas do gestor à consultoria contábil.

\subsubsection{SOLUÇÕES E MELHORIAS PARA O PERÍODO DE PANDEMIA}

A constatação da crise econômica durante a pandemia trouxe a necessidade de busca por soluções e melhorias, inclusive no segmento referente à consultoria contábil. Em razão disso, compreendeu-se que as ferramentas da gestão empresarial estão intimamente ligadas com a inovação e as possibilidades de controle dos gastos da entidade, embasados, principalmente, pelos relatórios do fluxo de caixa, redução de custos e estimativas de capital de giro.

Em uma Instituição, os valores de caixa permanecem sempre em variação, em vista do aspecto mutável do negócio. Neste sentido, o fluxo de caixa e o capital de giro são vitais para a compreensão de como se organiza a empresa, o que possibilita ao seu administrador a adaptabilidade e competitividade em seu ramo.

De acordo com Bampi e Silva (2018), o fluxo de caixa compreende o relatório de contabilidade capaz de relatar as operações monetárias em um determinado período

RC: 102106

Disponível em: https://www.nucleodoconhecimento.com.br/contabilidade/consultoria$\underline{\text { contabil }}$ 
da empresa, capazes de trazer alterações no saldo do caixa. Ou seja, significa o retrato da entrada/saída de valor cambial do negócio do estabelecimento. Já na visão de Padoveze (2012), o fluxo de caixa é um fator crucial para o setor financeiro de uma empresa, uma vez que ele deve ser elaborado diária e mensalmente, a fim de determinar um fator conhecido como "ponto de equilíbrio", na variação entre ativo/passivo do negócio.

É válido ressaltar a relação que existe entre o balanço patrimonial, o capital de giro e o fluxo de caixa para o pequeno empreendedor. Santos (2013) explica que o capital de giro estabelece, dentro do balanço patrimonial de uma empresa, os ativos que estão disponíveis ao estabelecimento, tais como: contas a receber e estoque do pequeno negócio. Ou seja, representa os recursos de menor prazo aptos a movimentarem as finanças.

Portanto, é vital ao gestor que ele possua um bom controle de caixa, para que possa se programar em conformidade com seu orçamento mensal, custos de mão de obra, taxas devidas, dentre outras obrigações, que deverão ser realizadas dentro de um determinado período. Tal prazo pode variar conforme o tipo de organização e, geralmente, em casos de pequenas Instituições, se trata de um planejamento financeiro anual. Tudo isso advém de um controle de fluxo de caixa saudável (SUSTENERE, 2019).

Outro fator importante com relação ao caixa diz respeito à finitude de seu ciclo. Conforme o tipo de negócio ou a capacidade da empresa, este pode apresentar grande variabilidade. Ciclos de caixa mais breves tornam o capital de giro mais circulante durante um período anual, e por isso suas projeções financeiras são realizadas a partir de tal mensuração.

Esta análise traz diversos benefícios para o estabelecimento, entre eles pode-se citar: o controle de entrada e saída de valores financeiros dentro de um prazo, o que permite ao gestor antecipar-se quanto aos riscos, principalmente durante restrições econômicas; a busca de novos meios de arrecadação de recurso, considerando 
também a carência de mais capital de giro e, finalmente, a tentativa de redução de empréstimos a partir dos prognósticos de déficit ou superávit no balanço, que visa também o planejamento estratégico (SANVICENTE, 2013).

Dentro da busca de melhorias para os pequenos negócios, a consultoria contábil oferece oportunidades por meio do apoio das principais tomadas de decisões da empresa, para que se possa buscar soluções com ajuda do planejamento adequado e com a organização do capital de giro, de modo a trazer bons resultados, tanto no presente como no futuro da empresa.

Ao delimitar a importância da Contabilidade aos pequenos negócios, vemos sua atuação atenuadora no auxílio a diversos contratempos empresariais rotineiros a que o gestor da empresa tem contato, além de sua capacidade de operação remota, ao suprir as necessidades dessas empresas que normalmente não dispõem de um departamento contábil em suas dependências. Dessa forma, fica evidenciado pelos fatos supracitados um paralelo entre a importância da operacionalidade das Ciências Contábeis em auxílio a essa ramificação empresarial, que são as empresas de pequeno porte no período pandêmico, em relação às questões sociais e econômicas do Estado. (SUSTENERE, 2019).

\section{MATERIAIS E MÉTODOS}

Japiassú (2013) fala com clareza que este item do trabalho será lido incessantemente, assim o pesquisador deverá utilizá-lo para apresentar suas conquistas, de modo a sempre fazer menção ao que foi proposto nos objetivos gerais.

Trigueiro (2014, p. 30) é concludente quando diz que a metodologia se distingue nos significados, de forma que ela pode ser empregada com contextos diferentes para assim obter o objetivo do estudo, por meio da utilização de métodos ou técnicas da melhor forma que se adequarem à pesquisa.

RC: 102106

Disponível em: https://www.nucleodoconhecimento.com.br/contabilidade/consultoriacontabil 


\subsection{PROCEDIMENTOS METODOLÓGICOS}

Os procedimentos metodológicos têm como objetivo explicar, discutir e explorar um acontecimento, ocorrência ou fato, por meio de informações confiáveis, que são artigos e revistas acadêmicas, ou seja, está relacionado com explicar fatos e acontecimentos (PRAÇA, 2015).

O estudo em questão tem como base pesquisas bibliográficas, objetivas e puras, textos acadêmicos, monografias, as principais empresas do país e levantamentos estatísticos do Instituto Brasileiro de Geografia e Estatística - IBGE e Serviço Brasileiro de Apoio às Micro e Pequenas Empresas - SEBRAE. De acordo com o tema, buscou-se propor uma reflexão a respeito do importante auxílio das Ciências Contábeis ao setor empresarial no período da pandemia do novo coronavírus COVID-19, que afetou principalmente as entidades de pequeno porte.

\subsubsection{QUANTO À NATUREZA}

Os dados apresentados foram obtidos por meio de procedimentos qualitativos, que consistem em atividades ou investigações que podem ser designadas especificamente, como modo de associar as informações com a interpretação e a aplicação dos métodos (OLIVEIRA, 2011).

De acordo com Costa e Leandro (2016), para a chegada da conclusão das ideias expressas, fez-se necessária a análise e interpretação dos fenômenos externos e internos. Para discutir o impacto da crise sanitária nessas corporações, a pesquisa partiu dos materiais que permitiram o entendimento e apresentação das opiniões dos pesquisadores a respeito dos fatos abordados.

A pesquisa utilizou uma abordagem de natureza qualitativa, introduzida a partir de dados narrativos nos quais se desenvolveram o projeto: uma visão das causas inconversíveis dentro das empresas, trazidas pela maior crise sanitária já vista em todo o mundo. Com base nisso executou-se os objetivos que levaram a criação do 
trabalho, que relaciona o cenário pandêmico a econômica do país no que se refere ao ramo empresarial, com as estratégias fundamentais da consultoria contábil e sua extrema utilidade neste cenário.

\subsubsection{QUANTO AOS FINS}

Quanto aos fins, o presente projeto possui caráter descritivo, que se baseia em pesquisas documentais, literárias e fatos comprovados, com o intuito de propor uma reflexão sobre a importância do auxílio das Ciências Contábeis ao ramo empresarial no período da Pandemia COVID-19, que afetou principalmente as empresas de pequeno porte, pois, como bem-dito por Zanella (2012), é preciso apresentar a relação, pesquisar, desenvolver e sintetizar o conteúdo. Já de acordo com Vergara (2016), ao descrever o evento por completo é necessário que estude, compreenda e relacione todas as variantes.

\subsubsection{QUANTO AOS MEIOS}

Conforme Oliveira (2011), os métodos bibliográficos são realizados a partir de materiais já elaborados, como, por exemplo, artigos científicos, visto que a maioria dos estudos de pesquisas são desenvolvidas através de meios bibliográficos, que são essenciais para o início de novas pesquisas empíricas.

Para Severino (2013), a pesquisa bibliográfica deve ser efetuada aos poucos, de modo que o estudante possa analisar, pesquisar e explorar livros, monografias e revistas científicas, com intuito de acrescentar cada vez mais informações ao seu trabalho, por meio de fichamentos e citações.

As informações demonstradas neste trabalho têm como fonte de pesquisa materiais bibliográficos e documentais, uma ampla investigação baseada em coleta de dados obtidos por meio de livros, notícias e documentos, o que permite demonstrar e dar embasamento às ideias aqui contidas e ainda apresentar dados estatísticos das empresas de pequeno porte, as quais são alvo do estudo. 


\section{CONSIDERAÇÕES FINAIS}

Diante o exposto neste artigo, observou-se a relevância da consultoria contábil para o ramo empresarial, em especial para micro e pequenas empresas. A crise gerada no Brasil com a pandemia culminou em impactos severamente negativos, o que trouxe à tona a necessidade de serem encontradas alternativas viáveis para melhorias e resgate destas empresas. A ideia exposta neste estudo permitiu que se pudesse entender melhor de que modo os métodos contábeis desempenharam um importante papel na tomada de decisões da gestão empresarial, de modo que se revelaram como ferramentas cruciais para muitas empresas no mercado, em especial no que diz respeito aos pequenos negócios, o segmento econômico mais afetado pela crise, sobretudo ao levarmos em conta o número de fechamentos de estabelecimentos do ramo na época vigente.

Com base no presente estudo, percebeu-se que as empresas de pequeno porte, se comparada às demais categorias, foram as principais afetadas pela pandemia. Coincidentemente, estas empresas tendiam a ter uma consultoria contábil menos sólida, fator que levou ao encerramento de inúmeros negócios. Em resposta à problemática motivadora da pesquisa: de que forma a consultoria contábil pode auxiliar na gestão empresarial durante o período de crise? esclareceu-se que a consultoria contábil é de suma importância para os pequenos negócios, pois, de acordo com as leituras realizadas, aquelas empresas com melhor utilização da consultoria contábil apresentaram maior capacidade de decisão acerca de questões tributárias e operacionais, o que gerou vantagens estratégicas nas ações de contratação, realocação de recursos e reorganização do capital de giro durante os períodos de isolamento.

Por outro lado, estabelecimentos com menor apoio do profissional contábil demonstraram deficiência nos aspectos básicos de planejamento financeiro. Concluímos, então, que o reflexo da consultoria contábil na gestão empresarial foi o grande facilitador do planejamento estratégico durante o auge da pandemia, que auxiliou na adaptação das entidades no desenvolvimento de suas atividades neste

RC: 102106

Disponível em: https://www.nucleodoconhecimento.com.br/contabilidade/consultoria$\underline{\text { contabil }}$ 
período. Concluímos ainda que houve importantes contribuições da contabilidade gerencial para ordenamentos no fluxo de caixa, prognósticos de capital de giro, variação de preços de produto e demonstrativo de resultados de exercício financeiro - fatores que comprovaram a eficácia da contabilidade para redução dos reflexos da pandemia no que concerne ao segmento empresarial de menor porte, a partir da hipótese levantada.

Ao se levar em consideração os fatos, percebe-se como a gestão contábil possui uma ligação com o setor fiscal, financeiro e pessoal da pequena empresa. Esta ciência demonstrou a capacidade de auxiliar e mediar a relação entre o gestor e seus funcionários, mesmo em um período de crise sanitária global, acontecimento que evidencia sua importância social. Mesmo com as adversidades do momento histórico vivido, o apoio do profissional contábil demonstrou ser eficiente ao conciliar as necessidades da empresa com os novos desafios propostos.

\section{REFERÊNCIAS}

ALMEIDA, L. S. F. de. et al. A Consultoria Contábil como Oportunidade de Negócios Profissionais-um Estudo Documental. Pensar Contábil, v. 20, n. 72, 2018.

ALVARENGA, F. de. O. Profissionais contábeis e a crise econômica instaurada pela COVID-19: um estudo na cidade de São João Del-Rei - MG. In: XVII Congresso USP de Iniciação Científica de Contabilidade, São Paulo - SP, 2020.

BAMPI, C.; SILVA, H. A. C. A Contabilidade Gerencial como Ferramenta de Gestão em Uma Microempresa de Lucas do Rio Verde: Estudo de Caso da Empresa Lima Felisberto \& Cia Ltda ME. Revista Científica Multidisciplinar Núcleo do Conhecimento, Ano 03, Ed. 05, Vol. 01, pp. 107-146, maio de 2018. ISSN:24480959.

BRASIL. Lei n. 14.020, 10 de janeiro de 2002. Institui o Programa Emergencial de Manutenção do Emprego e da Renda em 20 de Março de 2020. Disponível em: 
http://www.planalto.gov.br/ccivil_03/_ato2019-2022/2020/lei/L14020.htm. Acesso em: 30 de out. 2021.

. MEDIDA PROVISÓRIA № 944, DE 3 DE ABRIL DE 2020. Institui o Programa Emergencial de Suporte a Empregos. Disponível em: http://www.planalto.gov.br/ccivil_03/_Ato2019-2022/2020/Mpv/mpv944.htm. Acesso em: 30 de out. 2021.

. MEDIDA PROVISÓRIA № 1.046, DE 27 DE ABRIL DE 2021. Dispõe sobre as medidas trabalhistas para enfrentamento da emergência de saúde pública de importância internacional decorrente do coronavírus (covid-19). Disponível em: http://www.planalto.gov.br/ccivil_03/_ato2019-2022/2021/Mpv/mpv1046.htm. Acesso em: 30 de out. 2021.

CAMPOS, A. C. Agência Brasil: IBGE: $62,7 \%$ das empresas foram afetadas negativamente pela pandemia. 2020. Disponível em: https://agenciabrasil.ebc.com.br/economia/noticia/2020-07/ibge-624-das-empresasforam-afetadas-negativamente-pela-pandemia/. Acesso em: 30 de out. de 202.1

CARDOSO, J. A. de. L. A crise que não se parece com nenhuma outra: reflexões sobre a "corona-crise". Revista Katálysis, v. 23, p. 615-624, 2020.

CAVALCANTE, J. R. et al. COVID-19 no Brasil: evolução da epidemia até a semana epidemiológica 20 de 2020. Epidemiologia e Serviços de Saúde, v. 29, n. 4, 2020.

CHIAVENATO, I. Introdução à teoria geral da administração. $5^{\text {a }}$ ed. São Paulo:Atlas, 2018.

CHIAVENATO, I. Administração geral e pública: provas e concursos. $5^{a}$ ed. Barueri: Manole, 2018.

CONRADO, C. 0 que é contabilidade gerencial. Gestta, 2020. Disponível em: https://www.gestta.com.br/contabilidade-gerencial/. Acesso em: 26 de set. de 2021. 
COSTA, A. P. N. da.; LEANDRO, L. A. de. L. 0 atual cenário das micro e pequenas empresas no Brasil. 13ª ed. Resende: Aedb, 2016.

CREPALDI, S. A. Contabilidade gerencial, teoria e prática. 3a ed. São Paulo: Atlas, 2012.

DIAS FILHO, F. F.; SALES, L. de. F. O orçamento como instrumento contábil de controle e apoio à gestão das organizações modernas: um estudo com concessionárias de veículos de Belo Horizonte. Revista Mineira de Contabilidade, Ano 15, n. 56, p. 20-25, out./nov./dez. 2014.

G1- Entenda os impactos da pandemia de coronavírus nas economias globais e brasileiras. Portal de notícias G1, 2020. Site Disponível em: https://g1.globo.com/economia/noticia/2020/02/26/entenda-os-impactos-do-avancodo-coronavirus-na-economia-global-e-brasileira.ghtml./. Acesso em: 21 de ago. de 2021.

GANDRA, A. Indicador aponta impactos da covid-19 na economia brasileira. Agência Brasil, $2020 . \quad$ Disponível em: https://agenciabrasil.ebc.com.br/economia/noticia/2020- 05/indicador-apontaimpactos-da-covid-19-na-economia-brasileira. Acesso em: 26 de set. de 2021.

IBGE - Instituto Brasileiro de Geografia e Estatística. Desemprego recua para $\mathbf{1 3 , 7 \%}$ e atinge 14,1 milhões de pessoas no tri até julho. Site Disponível em: https://agenciadenoticias.ibge.gov.br/agencia-noticias/2012-agencia-denoticias/noticias/31732-desemprego-recua-para-13-7-e-atinge-14-1-milhoes-depessoas-no-tri-ate-julho./. Acesso em: 30 de out. de 2021.

INDIO, C. Pandemia fecha 39,4\% das empresas paralisadas, diz IBGE. Agência Brasil, Rio de Janeiro - RJ, 2020. Site Disponível em: https://agenciabrasil.ebc.com.br/economia/noticia/2020-07/pandemia-fecha-394-dasempresas-paralisadas-diz-ibge. Acesso em: 22 de ago. de 2021. 
IRAJÁ, V. Coronavírus: Economia brasileira pode sofrer efeitos por mais de dez anos. Veja, 2020. Disponível em: https://veja.abril.com.br/economia/coronaviruseconomiabrasileira-pode-sofrer-impactos-por-mais-de-dez-anos/. Acesso em: 26 de set. de 2021.

LEMES, A.; PISA, B. Administrando micro e pequenas empresas. São Paulo: Elsevier Brasil, 2010.

JAPIASSÚ, A. M. How to prepare and submit abstracts for scientific meetings. Revista Brasileira de Terapia Intensiva, v. 25, n. 2, p. 77-80, 2013.

KRUEGER, N. Coronavírus: O papel do contador e os efeitos da pandemia na sua empresa. Pronta serviços contábeis, 2020.

Disponível em: https://www.prontasc.com.br/coronavirus-o-papel-do-contador/. Acesso em: 26 de set. de 2021.

LACERDA, W. B. A importância do controle financeiro para os MEIS: um estudo para verificar o uso das ferramentas contábeis no MEI - Microempreendedores individuais da Serra, ES, 2016, 19 p. Disponível em: https://multivix.edu.br/wpcontent/uploads/2018/07/revista-espaco-academico-v07-n02-artigo-04.pdf. Acesso em: 26 de set. de 2021.

LIMA, B. M. de. S.; CASTOR, V. R.; COSTA, E. D. M. Contabilidade gerencial como ferramenta de gestão para o crescimento dos Microempreendedores Individuais (MEI). Revista Científica Multidisciplinar Núcleo do Conhecimento, Ano 03, Ed. 08, Vol. 01, 2018.

MARION, J. C. Contabilidade empresarial. 15ª ed. São Paulo: Atlas, 2009.

MATTEI, L.; FRONZA, M. C.; HEINEN, V. L. Trinta dias de anúncios de medidas econômicas para enfrentar os impactos da Covid-19: breve balanço de um desastre anunciado. NECAT, TD 037/2020. 2020. Disponível em: https://necat.ufsc.br/td037-2020/. Acesso em: 12 nov. 2021. 
ENCARNAÇÃO, L. V. et al. A importância da informação contábil no processo de tomada de decisão nas micro e pequenas empresas. Revista Contemporânea de Contabilidade, v. 10, n. 19, p. 119-140, 2013.

OLIVEIRA, A. C. M. de.; FERREIRA, V. C. do. P. O Profissional Contábil como Ferramenta na Prática da Legislação Trabalhista no Município de IcóCeará/Accounting Professionals as a Tool in the Practice of Labor Legislation in the Municipality of Icó-Ceará. Revista de Psicologia, v. 13, n. 48, p. 342-360, 2019.

OLIVEIRA, G. P. de. Contabilidade tributária. 3aㅗ ed. São Paulo: Saraiva, 2013.

OLIVEIRA, U. S. Consultoria contábil como ferramenta potencial na iniciação empresarial, no ramo de comércio varejista de alimentos: Estudo de caso da empresa X, localizada na cidade de Barreiras-BA. 2013. Disponível em: https://semanaacademica.org.br/system/files/artigos/artigouillian.pdf. Acesso em: 23 de mar. 2021.

OLIVEIRA, Maxwell Ferreira. Metodologia científica: um manual para a realização de pesquisas em administração. Catalão: Universidade Federal de Goiás, 2011.

OPAS, Organização Pan-Americana de Saúde. Folha informativa sobre COVID-19, Disponível em: https://www.paho.org/pt/covid19/historico-da-pandemia-covid-19/. Acesso em: 30 de out. de 2021

ORELLANA, J. D. Y. et al. Excesso de mortes durante a pandemia de COVID-19: subnotificação e desigualdades regionais no Brasil. Cadernos de Saúde Pública, v. 37, n. 1, 2021.

PADOVEZE, C. L. Contabilidade Gerencial: um enfoque no Sistema de Informação Contábil. 8ª ed. São Paulo: Atlas, 2012. 
PEREIRA, J. C. A.; ALENCAR, R. C. de. Contabilidade tributária: entendendo a lógica dos tributos e seus reflexos sobre os resultados das empresas. São Paulo: Atlas, 2010.

PESSÔA, L. C.; COSTA, G. da.; MACCARI, E. A. As micro e pequenas empresas, o Simples Nacional e o problema dos créditos de ICMS. Revista Direito GV, v. 12, n. 2, p. 345-363, 2016.

PRAÇA, F. S. G. Metodologia da pesquisa científica: organização estrutural e os desafios para redigir o trabalho de conclusão. Revista Eletrônica Diálogos Acadêmicos, v. 8, n. 1, p. 72-87, 2015.

RODRIGUES, M. A. Políticas Públicas. São Paulo: PubliFolha, 2010.

SANTOS, S. D. Funções da Contabilidade e Princípios Fundamentais da Entidade - $\quad$ Uniderp, $2013 . \quad$ Disponível em: semanaacademica.org.br/system/files/artigos/funcoesdacontabilidadeeprincipiofunda mentaldaentidade.pdf . Acesso em: 08 de abr. 2021.

SANVICENTE, A. Z.; SANTOS, C. da. C. Orçamento na administração de empresas: planejamento e controle. $2^{\underline{a}}$ ed. São Paulo: Atlas, 2009.

SEVERINO, A. J. Metodologia do trabalho científico. 1a ed. São Paulo: Cortez, 2013.

SOBRAL, J. A.; CARDOSO, R. C.; SANCHES, G. A. F. A gestão do capital de giro das micro e pequenas empresas. Revista Fateb Científica, v. 1, n. 1, p. 95-126, 2017.

SCHULTZ, G. Introdução à gestão de organizações. Universidade Federal do Rio Grande do Sul. $1^{\text {a }}$ ed. Porto Alegre: Editora da UFRGS, 2016.

SEBRAE, Estudo de Pesquisa: As Pequenas Empresas do Simples Nacional. Brasília, 2011. Disponível em: 
https://www.sebrae.com.br/sites/PortalSebrae/estudos_pesquisas/empresa-depequeno-portedetalhe8,8e5713074c0a3410VgnVCM1000003b74010aRCRD./. Acesso em: 14 de ago. 2021.

SEBRAE - Serviço Brasileiro de Apoio às Micro e Pequenas Empresas Características do Empreendedor - Sebrae e Caixa vão ampliar o acesso de pequenos negócios a crédito. Site Disponível em: https://www.sebrae.com.br/sites/PortalSebrae/artigos/sebrae-e-caixa-vao-ampliar-oacesso-de-pequenos-negocios-a credito,9c10d1e079a71710VgnVCM1000004c00210aRCRD?vgnextrefresh=1./. Acesso em: 26 de mai. 2021.

SEGATO CONTABILIDADE. Saiba qual é a importância da contabilidade gerencial. 2020. Disponível em: https://segatocontabilidade.com.br/importanciacontabilidade-gerencial/. Acesso em: 26 de set. 2021.

SOUZA, F. I; DA SILVA PINHEIRO, Márcia Teixeira. Contabilidade Tributaria: simples nacional no âmbito acional no que se concerne as micro e pequenas empresas. Revista Científica Semana Acadêmica, Ano MMXIII, v. 47, 2013.

STAGE. Contabilidade gerencial: como utilizar essa ferramenta estratégica. 2019 https://rockcontent.com/blog/contabilidade-gerencial/. Acesso em: 25 de set. 2020.

SUSTENERE. A importância da contabilidade no processo de desenvolvimento do microempreendedor individual (MEI). 2019. Disponível em: http://sustenere.co/index. php/rbadm/article/view/3122. Acesso em: 26 set. 2020.

TRIGUEIRO, R. de M. Metodologia científica. Londrina: Editora e Distribuidora Educacional S.A., 2014.

VERGARA, S. C. Projetos e relatórios de pesquisa em administração. $16^{\underline{a}}$ ed. São Paulo: Atlas, 2016.

RC: 102106

Disponível em: https://www.nucleodoconhecimento.com.br/contabilidade/consultoriacontabil 
ZANELLA, L. C. H. Metodologia de estudo e de pesquisa em administração. $2^{a}$ ed. Florianópolis: Departamento de Ciências da Administração / UFSC, 2012.

Enviado: Outubro, 2021.

Aprovado: Novembro, 2021. 